\title{
Fruit flies (Diptera: Tephritidae) on vegetable crops in Reunion Island (Indian Ocean): state of knowledge, control methods and prospects for management
}

\author{
Philippe RYCKeWAERT ${ }^{1 *}$, Jean-Philippe DEGUINE ${ }^{2}$, Thierry BrÉVAULT ${ }^{3}$, Jean-François VAYSSIÈRES ${ }^{4}$
}

${ }^{1}$ Cirad, UPR HortSys,

TA B-103/L, CSIRO,

Campus Int. Baillarguet,

F-34398 Montpellier, France

philippe.ryckewaert@cirad.fr

${ }^{2}$ Cirad, UMR PVBMT, Stn. Ligne-Paradis, Pôle 3P,

7 chemin de I'IRAT,

F-97410 Saint-Pierre, La

Réunion, France

${ }^{3}$ Cirad, UR SCA, Univ. Arizona, Dep. Entomol., Forbes 410, PO Box 2100 (36), Tucson AZ 85721, U.S.A.

${ }^{4}$ Cirad, UPR HortSys, IITA, 08 BP 0932, Tri postal Cotonou, Bénin

\begin{abstract}
Fruit flies (Diptera: Tephritidae) on vegetable crops in Reunion Island (Indian Ocean): state of knowledge, control methods and prospects for management.

Abstract -- Significance of fruit flies in vegetable crops. Vegetable crops hold a key position in agricultural production in Reunion (Indian Ocean); however, many pests and diseases threaten the profitability of this agricultural sector. Fruit flies (Diptera: Tephritidae) figure among the main pests for solanaceous crops and cucurbits (cucumber, zucchini, melon, etc.). Losses of as much as $80 \%$ of tomato and $100 \%$ of cucurbit crop harvests have been frequently observed. Inventory and distribution. Four fruit fly species belonging to the Tephritidae family cause major damage to vegetable crops in Reunion: Bactrocera cucurbitae (Coquillet), Dacus ciliatus Loew and D. demmerezi (Bezzi) on Cucurbitaceae, and Neoceratitis cyanescens (Bezzi) on Solanaceae (primarily the tomato). Distribution of each of them is presented. Biology and behavior. A few studies on the biology and behavior of the four fruit flies were conducted in Reunion in the late 1990s. Their main biological characteristics are summarized. Population control methods used in Reunion. Various methods such as chemical control, preventive measures (sanitation), physical control, biotechnical control [colored traps, the Male Annihilation Technique (MAT) and the Bait Application Technique (BAT)], and biological control currently used in Reunion against fruit flies are reported. Other control methods such as Integrated Pest Management and the Sterile Insect Technique are not used in Reunion. Prospects for implementing agro-ecological management of vegetable fruit flies in Reunion. This part presents research actions implemented in fly bio-ecology, research actions into the genetic structure of populations and design of an agro-ecological management scheme for vegetable fruit flies. Conclusions. The control methods used independently have not been successful to effectively control tephritid populations. A more integrated approach is required, also taking into account the landscape scale and its mosaic of habitats, especially wild plants, whose role must be considered within a framework of agro-ecological management of these pest populations.
\end{abstract}

Reunion / vegetable crops / Tephritidae / Bactrocera cucurbitae / Dacus ciliatus / Dacus demmerezi / Neoceratitis cyanescens / pest control / control methods

Les mouches des fruits (Diptera : Tephritidae) sur légumes à la Réunion (océan Indien) : état des connaissances, méthodes de contrôle et perspectives de gestion.

Résumé -- Importance des mouches des fruits en cultures maraîchères. Les cultures maraîchères occupent une position clé dans la production agricole à la Réunion (océan Indien), toutefois, de nombreux ravageurs et maladies menacent la rentabilité de ce secteur agricole. Les mouches des fruits (Diptera : Tephritidae) figurent parmi les principaux ravageurs des solanacées et des cucurbitacées (concombre, courgette, melon, etc.). Des pertes de près de $80 \%$ des récoltes de tomate et de $100 \%$ de cucurbitacées ont été fréquemment observées. Inventaire et distribution. Quatre espèces de mouches des fruits appartenant à la famille des Tephritidae provoquent des dommages importants aux cultures légumières à la Réunion : $\mathrm{BaC}$ trocera cucurbitae (Coquillet), Dacus ciliatus Loew et $D$. demmerezi (Bezzi) sur les cucurbitacées, et Neoceratitis cyanescens (Bezzi) sur les solanacées (principalement les tomates). La distribution de chacun d'eux est présentée. Biologie et comportement. Quelques études sur la biologie et le comportement des quatre mouches des fruits ont été menées à la Réunion dans les années 1990. Leurs principales caractéristiques biologiques ont été résumées. Méthodes de contrôle des populations utilisées à la Réunion. Diverses méthodes utilisées actuellement à la Réunion contre ces mouches des fruits sont exposées : lutte chimique, mesures préventives (assainissement), contrôle physique, contrôle biotechnique [pièges colorés, technique d'élimination des mâles (MAT) et technique d'utilisation d'appâts (BAT)] et lutte biologique. D'autres méthodes de lutte comme la lutte intégrée, et la technique des insectes stériles ne sont pas utilisées à la Réunion. Perspectives de mise en oeuvre de la gestion bio-écologique des mouches de fruits en culture maraîchère à la Réunion. Cette partie présente les actions de recherche mises en œuvre en bioécologie de la mouche, les actions de recherche sur la structure génétique des populations et la conception d'un système de gestion agro-écologique pour les mouches des fruits des légumes. Conclusions. Les méthodes utilisées indépendamment les unes des autres n'ont pas prouvé leur efficacité pour contrôler les populations de téphritides. Une approche plus intégrée est nécessaire qui prendrait en compte l'échelle du paysage et de sa mosaïque d'habitats, en particulier les plantes spontanées dont le rôle doit être considéré dans le cadre d'une gestion agro-écologique des populations de ces ravageurs.

Réunion / plante légumière / Tephritidae / Bactrocera cucurbitae / Dacus ciliatus / Dacus demmerezi / Neoceratitis cyanescens / lutte antiravageur / méthode de lutte 


\section{Significance of fruit flies in vegetable crops}

Vegetable crops hold a key position in agricultural production in Reunion Island (Indian Ocean) due to the number of farmers involved and the income generated by this industry. So besides sugar cane, Reunion's historical crop, vegetable production represented nearly $42000 \mathrm{t}$ in 2006 , with a surface area of 1800 ha, i.e., slightly less than fruit production [1]. However, many pests and diseases threaten the profitability of this agricultural sector [2], forcing farmers to resort to synthetic pesticides with all the risks that this entails for human health and the environment. Fruit flies (Diptera: Tephritidae) figure among the main pests for solanaceous crops (in particular, fieldgrown tomato, Lycopersicum esculentum Mill.) and cucurbits: cucumber (Cucumis sativus L.), zucchini (Cucurbita pepo L.), melon (Cucumis melo L.), etc. Losses of as much as $80 \%$ of tomato and $100 \%$ of cucurbit crop harvests have been frequently observed.

According to farmers, fruit fly damage to vegetable crops has become significantly greater since the 1990s, although the various species concerned had been reported for several decades [3]. Broad-spectrum insecticides, often unauthorized for the given crop, have been used at high doses and frequencies, without rotation of chemical families, which has probably negatively impacted on natural enemies of these pests and led to development of resistance. These practices have led to the impossibility of maintaining populations below an economic threshold. Besides poor management of this chemical control and the use of unsuitable insecticides, other hypotheses regarding changes of cropping practices could explain these proliferations: spatial expansion and, during other seasons of cultivated and wild host plants, lack of rotation and fallow, introduction of more susceptible varieties, and relaxation in the application of prophylaxis recommendations.

\section{Inventory and distribution}

Four fruit fly species belonging to the Tephritidae family cause major damage to vegetable crops in Reunion: Bactrocera cucurbitae (Coquillet), Dacus ciliatus Loew and D. demmerezi (Bezzi) on Cucurbitaceae, and Neoceratitis cyanescens (Bezzi) on Solanaceae (primarily the tomato) $[4,5]$. Other species specialized on fruit crops such as Ceratitis capitata (Wiedemann) and Bactrocera zonata (Saunders) have been reported on vegetable crops, but do not cause significant damage in Reunion Island (S. Quilici, pers. comm.).

Bactrocera cucurbitae, the melon fly, has been relatively recently introduced into Reunion (identified in 1972), probably from India via Mauritius [3]. Its current distribution ranges from South Asia, whence it originates, to many Pacific Islands (including Hawaii) and, more recently, the Seychelles and Africa, where it is currently spreading [6]. Its biology is relatively well known, and the species has been much studied in India, South-East Asia and Hawaii [7]. It is a thermophilic species not commonly found at altitudes over $800 \mathrm{~m}$ in Reunion.

Dacus ciliatus, the Ethiopian cucurbit fly, was probably introduced from Africa whence it originated. It has been reported in Reunion since 1964 [4]. It is also present in most of the South-West Indian Ocean islands, but also in India and South-East Asia [8]. It has been much less studied than the species above. It is a eurythermal species, since it has been found in Reunion from the shore to high-altitude areas (at least $1200 \mathrm{~m}$ ).

Dacus demmerezi, the Indian Ocean cucurbit fly, is a more stenothermal species, probably originating from the Madagascan plateau. It was first reported in Reunion in 1972 [3]; it is also present in Mauritius. Due to its limited distribution, the species has been very little studied, although this species causes sometimes major damage in high-altitude areas of Reunion Island (above $600 \mathrm{~m}$ ). As such, it is considered to be a secondary damaging species in Mauritius, a low-altitude island (P. Sookar, pers. comm.).

Each of these three species may potentially cause entire destruction of the crop, although generally two species are found coexisting in the same location, according to the altitude and season. Relatively mild attacks have been registered on certain zucchini, cucumber and melon cultivars [4]. 
The tomato fruit fly, Neoceratitis cyanescens, has been described in Madagascar, where it is probably indigenous. It is not considered as a major pest there, though we have been unable as yet to explain this observation. The species was introduced into Reunion and then into Mauritius, where the first damage was reported in 1951 and 1958, respectively [9]. Its presence in Mayotte (Comoro Archipelago) was only reported in 1992 [4], while it was present a long time before this first mention. In Reunion Island, the distribution area of the tomato fly extends from the coast to an altitude of $1500 \mathrm{~m}$, according to the availability of host plants [3]. We observed that there are no flies present at altitude during the cool season but no study has been conducted to test diapause, quiescence or migration hypotheses.

\section{Biology and behavior}

A few studies on the biology and behavior of these insects were conducted in Reunion Island in the late 1990s. We summarized the main biological characteristics of the four species mentioned (table I).

The tomato fruit fly, Neoceratitis cyanescens, is one of the main pests of solanaceous crops, on which it stings young fruits to lay its eggs. This species is specialized on the Solanaceae family, represented by around twenty species in Reunion, but only eight are considered as host plants [10]. It causes significant damage to field-grown tomato and, to a lesser extent, to the sweet pepper (Capsicum annuum L.), eggplant (Solanum melongena L.), tree tomato [Cyphomandra betacea (Cav.)] and chilli pepper (Capsicum frutescens $\mathrm{L}$.). Other wild or sub-indigenous Solanaceae such as the black nightshade (Solanum americanum Mill.), bug weed (S. mauritianum Scop.) and turkey berry (S. torvum Sw.) serve as breeding reservoirs. The wide distribution of these host plants on the island up to an altitude of $1500 \mathrm{~m}$, as well as abundant, nearly uninterrupted fruit bearing, offer suitable conditions for the development of tomato fruit flies all year round [11]

Mating starts from the second day after emergence of the adults. At $25^{\circ} \mathrm{C}$, the females mate very frequently, about three out of four days [12]. The pre-oviposition period lasts from 4 to 6 days. Larval development in the fruit lasts from 10 to 15 days [13]. Upon maturing, the larvae burst out of the fruit, and then pupate in the soil. As pupation lasts around ten days, the development cycle from egg to adult takes 21 to 31 days [9, 13, 14]. In response to odors released by host plants, and carried by the wind, the tomato fly females are guided to the source by successive flights [5]. After arriving at the host habitat, visual stimulation alone is sufficient to guide their landing onto the fruit [15]. Females respond strongly to a bright orange-colored sphere, which probably mimics the host fruit $[15,16]$. However, the incorporation of appropriate olfactory signals enhances their search efficiency [17]. The response to stimuli is affected by the nature and structure of the habitat [17]. The response of females to a host fruit type visual signal depends on their age and their egg load, but also their nutritional condition [15]. This response is at its greatest in the afternoon, the preferred period for ovipositing [18].

Bactrocera cucurbitae, Datus ciliatus and $D$. demmerezi are three oligophagous species specialized mainly on the Cucurbitaceae family, the first two developing on 16 species and the latter on 13 species [4]. Of these 16 species, four are wild Cucurbitaceae - Coccinia grandis (L.) Voigt, Momordica charantia L., Cucumis anguria L. and Lagenaria sphaerica (Sonder) Naudin which act as reservoir plants, enabling above all the reproduction of $B$. cucurbitae and $D$. ciliatus all year round, primarily on the shore with the driest wind [4]. These two species are polyvoltine at low altitude. In Reunion Island, besides Cucurbitaceae, we can report rare attacks on the tomato, wild passion fruit (Passiflora foetida L.) and passion fruit (Passiflora edulis Sims) [4]. We noted that $B$. cucurbitae attacks the tomato and papaya little or not at all (Carica papaya L.) in this island, whereas it causes damage to these crops in other parts: India [19], Cameroon [20], Hawaii [21] and Benin [6]. This probably results from competition for resources with $N$. cyanescens for the tomato, and with various fruit fly species (Ceratitis spp.) that might develop on the 


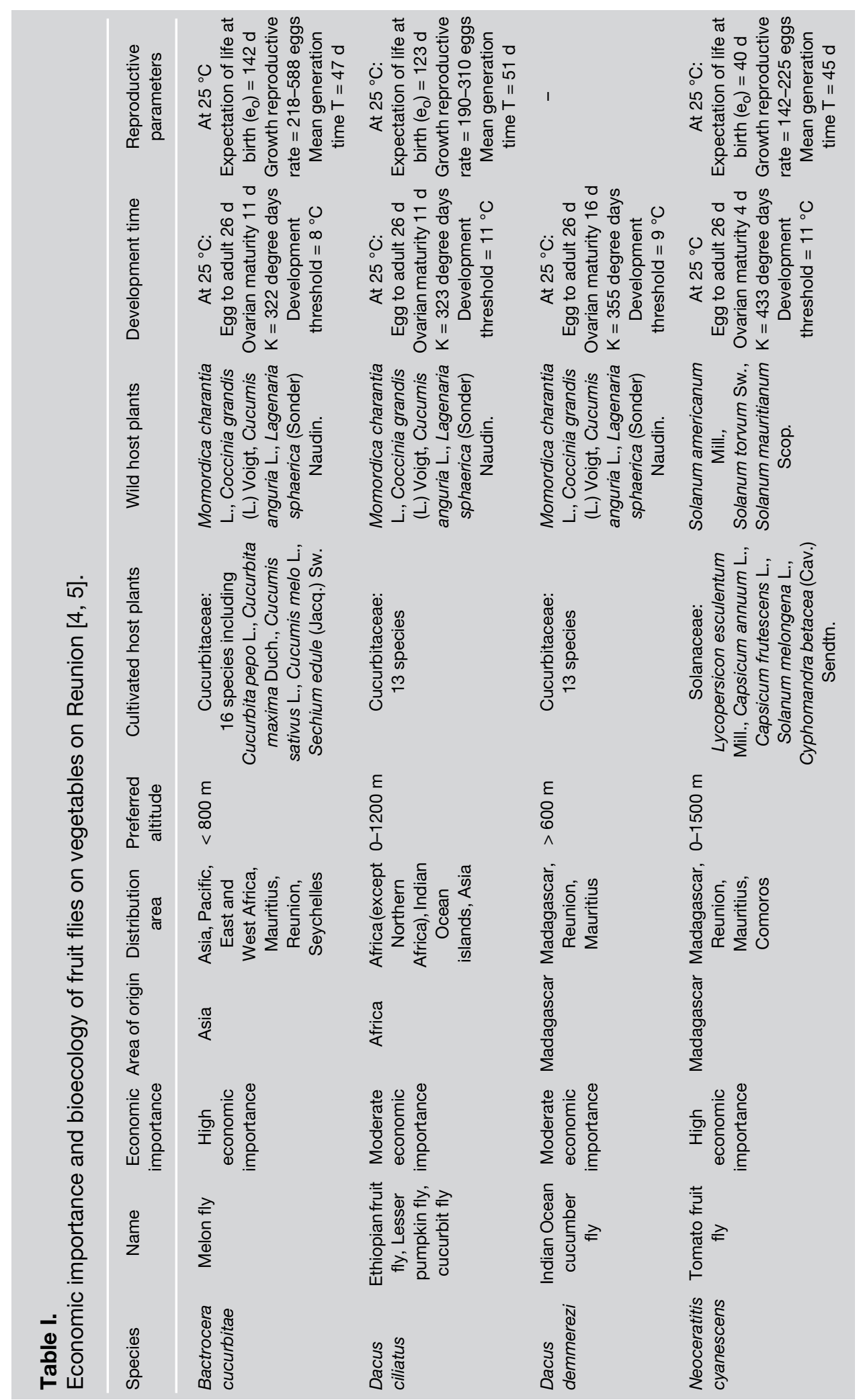


papaya in Reunion. It could also involve a special biotype of this species, but this aspect has not been investigated.

The fruit of cultivated species is attacked by females of the three species within around ten days of fruit setting and sometimes even before the ovary has been fertilized, as it is often the case with the pumpkin and zucchini. Hence these fruits are generally punctured two days before fruit setting, the fruits of the watermelon [Citrullus lanatus (Thunb.)] are punctured two to six days after, and the fruits of the cucumber are punctured four to ten days after [22]. These three Dacini species may lay their eggs in either the vegetative part of the plant (stems) or in the floral organs (male and female flowers). These two biological characteristics relating to egg-laying may partly explain why some farmers do not identify the damage caused by these pests [4]. Furthermore, the extensive cropping systems (picking type) which are quite frequently encountered are a factor favoring development of Tephritidae populations because of (i) the absence of cropping and control practices, and (ii) the presence of "reservoir plants" through the absence of human intervention.

Study of demographic parameters of $D$. ciliatus showed a high biotic potential, which could partly explain its wide geographic distribution in Asia and Africa [23], just like B. cucurbitae [24]. Experiments on the behavior of $D$. ciliatus showed that the orange color was significantly more attractive to sexually mature females, and that the yellow color was significantly more attractive to sexually mature males [25]. These responses of D. ciliatus to visual stimuli could be used to improve trapping of this species as part of biotechnical control, as could the investigation of chemical stimuli.

The spatio-temporal distribution of these insects depends both on biotic factors (specific bio-ecological characteristics, host fruit availability, presence of other competing species, etc.) and abiotic factors (temperature, humidity, wind, etc.). Populations are particularly high during the southern summer (December to March) both in terms of spatial distribution and density. Consequently, their economic impact on crops is considerable during this period.

\section{Population control methods used in Reunion Island}

In Reunion Island, control of fruit flies is still largely based on the use of insecticides. Research issues have gradually turned towards alternative methods, taking inspiration from work already conducted on orchard fruit flies in the island, or on vegetable fruit flies worldwide. We summarized the various methods currently used against these flies in Reunion Island (table II).

\subsection{Chemical control}

Until now, farmers have applied foliar insecticides directly onto plots in order to control either adults present in the crop directly via contact or inhalation, or adults arriving at the plot subsequently via a residual or repellent effect. Overall, farmers have reported the effectiveness of these sprayings, although they have not been proved by field experiments in the island. These applications have no effect on larvae survival, which are protected inside the fruits. Laboratory studies have demonstrated the efficacy of several active ingredients on imagoes [26, 27], but transposing this to the field did not necessarily give the same results.

The frequent and repeated use of various insecticides belonging to three main chemical families (organophosphates, carbamates and pyrethroids), has perhaps led to resistance, which could partly explain the increase in damage observed over the past few years, but no studies have been conducted on this issue in Reunion. Furthermore, these insecticide sprayings probably reduce populations of natural enemies (predators, parasitoids, etc.), as a natural pest control.

Observations of daytime activities of some fruit fly species demonstrated that only females entered the plot to lay eggs, whereas males or immature females remained located in the immediate surroundings of fields (e.g., hedges) to feed, mate or rest $[4,5]$. Hence treatments applied to the field will at best only affect part of the adult population.

\subsection{Preventive measures (sanitation)}

Unsellable fruits, especially those housing larvae, left on the ground or on plants, are 


\section{P. Ryckewaert et al.}

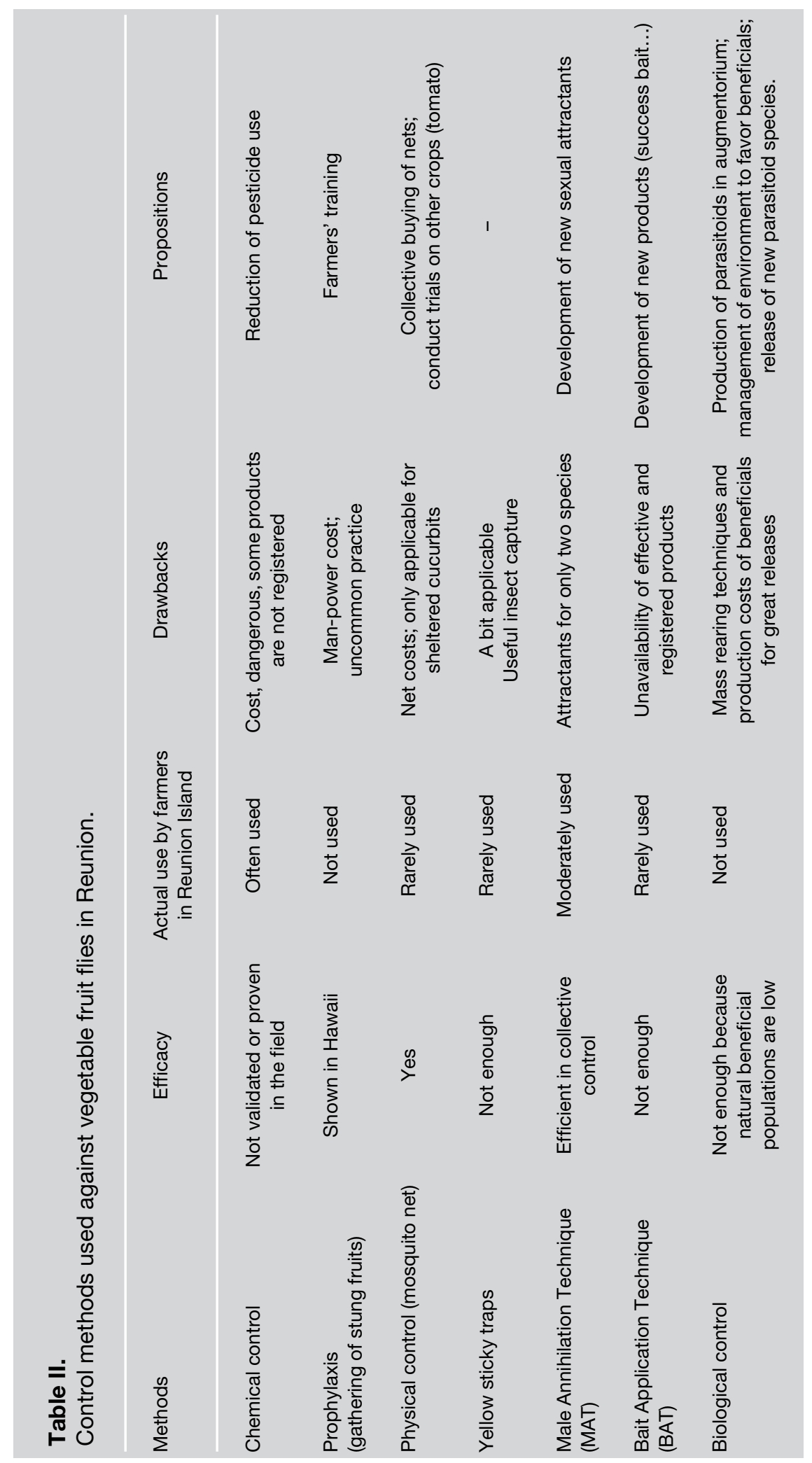


a major reservoir for the next generation [28]. Elimination of these fruits should be systematic so as to reduce subsequent infestations. It is also recommended to destroy crop residues after harvest. However, these principles are still little implemented by farmers in Reunion, above all for issues of custom and labor costs.

The absence of host plants (cultivated or not) during a period in principle offers little benefit on a single farm in view of the flies' high mobility capacities and their lifetime of several months. However, these periods exist at high altitude during the Southern winter (June to September), but we soon observe recolonization of the crops when the temperature increases, although we cannot say whether these are overwintering populations (very likely for $D$. demmerezi in view of its distribution primarily at high altitude), or migrants from lower altitude. Eliminating uncultivated host plants around the edges of plots, such as the wild bitter melon, does not seem to have much effect on infestation. Indeed, most Cucurbitaceous plots located in areas where they are not normally grown (big sugar cane cropping regions) but with bitter melons (Mormodica charantia) present around the edges, have always had very little infestation (pers. obs.). It would also seem that the permanent presence of suitable crops in a production area maintains the high population levels observed. For the tomato fruit fly, the importance of bug weed (Solanum mauritianum) as a source of infestation needs to be studied. Conversely, these indigenous plants may have a positive role, acting as auxiliary reservoirs (banker plants). Trials conducted in Hawaii demonstrated that implementing preventive measures in a production region reduced populations on their own by over $60 \%$ (E. Harris, pers. commun.), which emphasizes the usefulness of these practices on the scale of a whole production area, rather than on a single plot or farm.

\subsection{Physical control}

Mechanical protection of crops via nets or screens to prevent insect egg-laying is a solution already employed on some crops such as cabbage [29], and could be a way forward against flies. However, using agrotextile nets has often proven problematic under tropical conditions due to the plant being subjected to big temperature and humidity rises, causing poor plant development or development of diseases (pers. obs.). Furthermore, these nets prevent flower pollination, which is essential in most Cucurbitaceous plants, especially as fruit fly egglaying starts even before the female flowers open [4]. Finally, the cost of these nets remains prohibitive in Reunion Island, as well as the labor required to handle them. However, mini-tunnel systems communicating with hives have been tested with success in Senegal [30, 31]. Practices of individual fruit bagging using nets are sometimes employed in some countries with low labor costs [32]. In Guinea, straw protection of very young pumpkin and zucchini fruits has yielded beneficial results, significantly reducing infestations (J.-F. Vayssières, pers. obs.).

Observations, followed by a trial by the Fédération Départementale des Groupements de Défense contre les Organismes Nuisibles (FDGDON, St Paul, La Reunion), demonstrated that cucurbit flies do not enter open plastic tunnels housing cucumber crops, the openings of which are closed off by bird nets (mesh size around $3 \mathrm{~cm}$, black). The phenomenon has not currently been explained; the net may disrupt the flight behavior of the flies, preventing them from entering in spite of the large mesh size. Another case concerns open tomato crop shelters (without nets over the openings) with which all farmers observed very little tomato fly damage, although major attacks can be observed on neighboring open field crops. Although no studies have been conducted to date on this aspect, the behavior of $N$. cyanescens may be affected by the transparent plastic film, as it modifies the light spectrum [33]. This phenomenon is already known for other insects in greenhouses, where UV filtering through certain plastic films impairs movement or egg-laying [34].

\subsection{Biotechnical control}

Biotechnical control is defined as the use of stimuli or visual and chemical agents that 
affect the behavior or development of the target insect [35]. This involves using techniques that will act on the insects' behavior via visual or olfactory stimuli, and guide them to an attractive source, trapping or killing them, thereby enabling a count (monitoring) or elimination (mass trapping). Improving biotechnical control must be based on better knowledge of the bio-ecology and behavior of the species.

\subsubsection{Colored traps}

It has long been known that fruit flies are attracted by the color yellow. It is possible to use panels of this color, or bottles of oil covered with glue, and set them up within or around the crops (a traditional method used by some farmers in Reunion Island). Tests have been conducted on chayote [Sechium edule (Jacq.)], a cucurbit crop locally grown on vines, which demonstrated better attractiveness with yellow bottles put under the vine than those above it. Other more specific colors, as well as the shape of the glue-coated traps, have been tested [ 4 , $5,16,17]$. These types of visual traps, intended rather for tracking the development of populations, are not very practical as besides the drawbacks due to the glue we have found a lack of selectivity in the yellow traps, as many predator and pollinator insect species are also attracted. In addition, we have not observed a significant population or damage decrease by setting traps in a single plot in our trials.

\subsubsection{Male Annihilation Technique (MAT)}

A few chemical substances, known as parapheromones, have the property of strongly attracting the males of some fruit fly species in the same way as sexual pheromones. Consequently, these products can be used in trapping systems. Several types of traps, based on the "Tephritrap ${ }^{\circledR}$ " used in fruit orchards, have been tested locally. These were most often dry traps containing a parapheromone-soaked capsule or plate, with an added vapor action insecticide (dichlorvos, malathion).

Two vegetable fruit fly species present in Reunion, B. cucurbitae and D. demmerezi, are attracted by a known parapheromone, the cuelure. Comparative tests have been conducted with various diffusers: the one supplied locally by the FDGDON, comprising a wooden cube impregnated with cuelure and malathion, currently appears to be the most useful in terms of effectiveness, cost and availability in Reunion. As malathion in the long term may be withdrawn from the market, other active ingredients such as spinosad could replace it [36].

In vegetable producing areas, these traps can capture a very high number of males (sometimes hundreds per trap per week), which reflects the high population levels. However, this method cannot significantly reduce populations and damage when the traps are set up inside or around a single plot as the adults probably move to an entire area (reinfestation via migrations). In addition, uncaptured males are capable of fertilizing a number of females (polygyny), and the females also have the ability to live for several months. Hence this method used alone may be insufficient [37]. This constraint has also been observed with the use of sexual pheromones [38] which may, on the other hand, give good results as, for example, with forest moths such as Lymantria dispar (L.) [39], provided that the populations are low density and the infested area isolated.

Therefore, it would be necessary to apply a combined control method to an entire production area. A campaign against flies attacking chayote was conducted by the FDGDON using cuelure traps in an isolated production area located at an average altitude of $400 \mathrm{~m}$ in the South of the island. After several months of trapping, the quantity of trapped B. cucurbitae males had greatly decreased as $D$. demmerezi was barely present at this altitude. However, fruit damage did not decrease and the rearing of larvae taken from the fruit primarily produced $D$. ciliatus, a species not attracted by cuelure. Hence, generalized trapping led to the replacement of an initially dominant species by another less competitive species.

\subsubsection{Bait Application Technique (BAT)}

Fruit flies need water, carbohydrates and proteins to ensure their survival, but also for egg maturation. The foraging behavior 
for these nutrients can be exploited by attracting the flies with products providing them with these substances. Numerous products containing proteins or yeasts, or even plant-derived substances, have been used as attractants worldwide [40-44] used either in traps or mixed with an insecticide for spot treatments on crops.

These attractants can be used with two methods. First, McPhail-type liquid traps are used, in which the flies are attracted and drowned. Yet this device attracts few individuals compared to the parapheromone traps and so remains insufficient for significantly reducing populations, although the specificity is lower and the attraction applies to both sexes. Furthermore, there do not always seem to be correlations between the number of individuals trapped and the level of damage, but we have a lack of data. Nonetheless, these traps are good indicators of the species presence and their changes over time.

Spot sprayings, long since successfully used in fruit orchards [45], consist of applying to some plants or plant parts a food attractant acting as a lure, mixed with an insecticide. Several protein or yeast-based food attractants were tested in large outdoor cages with laboratory-reared flies. This type of attractant was tested in liquid form in McPhail-type traps. The products tested (Nulure $^{\circledR}$, Solbait ${ }^{\circledR}$, Hymlure ${ }^{\circledR}$, Corn Steep water $^{\circledR}$, Pinnacle $^{\circledR}$, Torula ${ }^{\circledR}$ and various yeasts including brewing waste derivatives) were all more effective than the Buminal ${ }^{\circledR}$ control, the only food attractant for fruit flies sold in France [46, 47]. However, authorization for their use is classified as minor usage in Reunion, which has not yet been defined, and they cannot yet be put on the market. Improvements in effectiveness by reducing the $\mathrm{pH}$ or increasing the concentration have also been observed to a certain degree, but using additives (borax, ammonium acetate) or using enzymes (papain) had no positive effect [48, 49], unlike the findings with other fruit fly species. Though the methodology has been gradually refined to eliminate some biases [50], we have not tested the effectiveness or repellent effect of only a few insecticides intended for mixing with attractants.
These experiments in field cages are, however, fairly remote from the reality of spot treatments, where small quantities of products are applied to the leaves in the form of drops, which will dry more or less quickly. Hence a new protocol for comparative tests in large cages has been proposed using dry traps containing an insecticide plate, a piece of maize leaf mounted on a wet piece of cotton, onto which a drop of a given volume of attractant is placed. The results proved to be contradictory depending on the replicates. Trials have started to this end to explain the variability of the responses observed, which appears to be related to the position of the traps in the cage relative to the sun, the time of fly activity, the temperature and the attraction by the maize leaf, wet piece of cotton and yellow color of the insecticide plate.

Field tests conducted in collaboration with several local partners (FDGDON, Plant Protection Service) provided an opportunity for testing a new product, GF 120 (= SYNEIS APPAT $\left.^{\circledR}\right)$, a mixture of a food attractant and a natural insecticide, spinosad), applied in spot spraying to the crop or border plants favorable to flies, such as maize. Indeed, studies in Reunion into fly behavior have demonstrated that the applications would gain effectiveness if applied around the edges of the plot [18], as it is done in West Africa [6]. These tests have not, however, demonstrated the effectiveness of GF 120 under the conditions of Reunion, even if the doses, concentrations or application frequency are increased, whereas it appears to be effective in other parts of the world [51]. Laboratory tests have confirmed its toxicity against several fly species [52] and we have observed it for ourselves in large outdoor cages, as in Mauritius [53]. Furthermore, studies on B. cucurbitae have demonstrated that the age of the flies, exposure time and product concentration had an effect on attractiveness and mortality [54].

A hypothesis may be drawn up regarding this lack of effectiveness in the field. As flies are highly mobile insects, it is highly likely that they are constantly arriving from surrounding host crops, where populations may be high. Furthermore, we do not know the remanence of attractants, and their rapid 
breakdown could also explain the phenomenon. It is also possible that the females have time to lay even before being eliminated by spot sprayings. However, according to manufacturer sources, GF 120 would be effective in fruit crops when applied to hundreds of hectares of single crop land, in an environment with few natural areas or little wild land. This situation is therefore different to that in Reunion where vegetable crop plots are piecemeal, and surrounded by a variety of habitats. Furthermore, tests conducted in Reunion [50] and the USA [55] have demonstrated that flies with protein-sufficient diets are much less attracted by attractants containing protein, such as GF 120 , for example. Hence it is highly possible that flies can easily find protein sources in a local context rich in food resources (plant exudates, excrement, maize pollen, fruits, etc.).

\subsection{Biological control}

Fruit flies have a number of natural enemies, which generally attack the eggs or larvae. However, these stages are more or less protected by the fruits hosting them, except when the larvae emerge from the fruit to pupate in the soil. They can then fall prey to various predators (including ants) and parasitoids. The eggs inserted under the fruit skin can also be parasited fairly easily by oophagous species, whereas only larvae near the edges of the fruit can be reached by other parasitoids. Adults may also be captured by various organisms (spiders, for example), but this aspect has still been little studied.

Several entomophagous species have been listed across the world, but their effectiveness is not always sufficient in economic terms. Only a few species are recognized as beneficial and have been introduced to various countries, and some of them to Reunion in the past few years, but not all are acclimated or are still at too low a level to have a useful action [56].

Psyttalia fletcheri (Silvestri) (Hymenoptera: Braconidae) is the most used parasitoid worldwide for controlling B. cucurbitae [57]. Its introduction into Reunion in 1995 and its installation have been a success [58], but the level of parasitism observed in the past few years is still low in crops $(<5 \%)$, including on plots without insecticides [4]. However, it is possible that the levels obtained from larvae in the fruit underestimate the real parasitism rate because some larvae could be parasited when they emerge from the fruit before pupation in the soil. Furthermore, we have not studied the effectiveness of this parasitoid against $D$. demmerezi and D. ciliatus, although it is known that this hymenopterous insect can parasite them in the laboratory [56]. The main P.fletcheri reservoir in Reunion appears to be the wild bitter melon (Mormodica charantia), which primarily hosts B. cucurbitae [4].

On the other hand, the effectiveness of this species has been demonstrated in Hawaii provided that pre-reared individuals are released in mass (over 60,000 individuals $\cdot \mathrm{ha}^{-1}$ per week) [59], which poses the problem of cost. A complementary technique aimed at increasing parasitoid populations consists of putting sting fruits in a cage (with larvae therefore partly parasited), the mesh of which enables emergent parasitoids to escape but prevents the flies from passing through. This technique used in Hawaii is known as the "augmentorium” (E. Harris, pers. commun.).

A fruit fly egg parasitoid, Fopius arisanus (Sonan) (Hymenoptera: Braconidae), has been recently imported to the island to control Bactrocera zonata, but a study has demonstrated that it cannot complete its cycle on B. cucurbitae and that it develops little on the three other species concerned [60].

In the cases of $D$. ciliatus, D. demmerez $i$ and $N$.cyanescens, the parasitoids are much less known, and further research would need to be conducted in their areas of origin, which are assumed to be in Africa and Madagascar. Some parasitoid species have been recently mentioned on $D$. ciliatus in Egypt [61]. In Reunion, very little data exists on parasitoids of $N$. cyanescens: the ones mentioned are Psyttalia near distinguenda (Granger) and Ps. insignipennis (Granger), but this parasitism seems to be occasional [5]. 


\section{Other control methods not used in Reunion}

\subsection{Integrated Pest Management}

Integrated Pest Management (IPM), developed since the 1970s in the Northern countries, has generally aimed to harmonize organic control with rational chemical control in a curative approach, with rather disappointing results in most situations [62]. Furthermore, there are no insecticides specific to fruit flies. Hence, as with other pests, fly control has until now been almost exclusively based on chemicals, where the insecticides used may subsequently end up on the fruits, in the soil and in the water tables, not to mention the adverse effects on useful fauna (entomophagous species, pollinators, etc.). For example, an experimental tomato plot managed without chemical sprayings in the South of the island exhibited major fruit damage due half to $N$. cyanescens and half to tomato fruitworm noctuid moth Helicoverpa armigera (Hubner), which does not normally cause damage in Reunion, probably controlled by broad-spectrum treatments applied against $N$. cyanescens.

Finally, we need to take into account all of the pests of the crops concerned, since their overall management may be difficult in some cases following the cessation of broad-spectrum insecticide applications.

\subsection{Sterile Insect Technique}

Also known as genetic control, the principle of the Sterile Insect Technique (SIT) consists of releasing very great quantities of males pre-sterilized by ionizing rays. They then compete with the wild males and mate with the females, which will lay sterile eggs. This method, which may form part of IPM, does, however, assume that the sterile males are much greater in number than the wild males and that their fitness for mating is unaltered. This technique has completely eradicated species such as B. cucurbitae on some Pacific islands [63, 64]. However, it poses several drawbacks, particularly in the context of Reunion. Firstly, the mass rearing of millions of individuals would need to be controlled over several years, which presupposes setting up a production factory. In the case of flies attacking vegetables in Reunion, the techniques and experience are known for just one species, B. cucurbitae, and it would be necessary to launch studies to develop large-scale rearing of three other species, especially since mass rearing of $N$. cyanescens and above all of D. ciliatus has always been problematic in the laboratory. There is also the added problem of the females' mating capacity throughout their lifetime with several males: for example, the $N$. cyanescens females mate nearly every day [5]. Moreover, following eradication of some species in other lands, species displacement phenomena through elimination of the competition have been observed [65]. Consequently, SIT should be applied simultaneously to the three species present on Cucurbitaceae in Reunion. Hence, for economic reasons and due to the relatively small crop surface areas concerned, it appears unlikely that this method will be implemented. It could possibly be profitable at a regional level, but not all lands are affected by the same species.

\section{Prospects for implementing agro-ecological management of vegetable fruit flies in Reunion}

\subsection{Approach and references}

The structure of landscape as a mosaic of habitats affects the spatio-temporal dynamic of insect populations. Landscape management may contribute to maintaining insect populations at non-harmful levels, by promoting faunistic balances and preserving biodiversity. This approach is based on agro-ecological pest management [66] and can be applied in particular in the form of management of their habitats or those of their natural enemies and of pollinators on expanded time, space and management scales [67]. Enhancement of beneficial fauna may be achieved through increasing plant diversity, whether cultivated (rotations, mosaics, intercropping, etc.) or uncultivated (borders, hedges, fallows, natural environments, etc.). This biodiversity also ensures better resilience of agro-systems [68]. 
Planting service plants around plots has several objectives depending on the species: a trap or repellent effect for pests ("push-pull"), or acting as a reservoir for beneficials (functional biodiversity). Regarding trap plants, the initial observations seem to indicate that the wild bitter melon (Mormodica charantia) is more attractive to B. cucurbitae females than the zucchini, which therefore appears to be protected, but the opposite clearly applies to D. ciliatus. Similarly, with traps placed in large field cages, we have found that bitter melon leaves were clearly more attractive to B. cucurbitae females than the same weight of zucchini leaves. The importance of this sub-indigenous plant as a parasitoid reservoir, however, is still limited as levels of parasitism remain low $(<10 \%)$ (P. Ryckewaert, unpublished).

Observations have shown that vegetable fruit flies could gather on certain field border plants on which they feed [69], mate [4] and rest [18]. Hence grasses such as maize, sorghum or sugar cane often act as shelter plants for these flies. Maize seems particularly favorable to these insects, which probably find water, exudates and pollen $[4,70]$, or even aphid honeydew or other nutrients. Therefore, it appears more logical to place traps or apply spot treatments to this type of plant rather than to the crop [51, 71, 72]. Finally, these plants may also promote development of beneficials, or host them.

The approach initiated in Reunion is consistent with the agro-ecological approach described above, the conceptual bases of which were summarized by Deguine et al. [73]. It is also completely consistent with the guidelines adopted in some countries for vegetable fruit fly control based on a largescale management approach (Area-Wide Pest Management) [74]. In Hawaii, a program of this type was initiated in 2000 on several hundred hectares, on several crops (cucurbits, papayas, etc.) and on several fruit fly species including B. cucurbitae, a species present in Reunion [75]. Besides the fact that Hawaii and Reunion exhibit numerous similarities, particularly in terms of agriculture and climate, the situation on this island in 2008 may be compared to that of Hawaii in 2000: significant fruit and vegeta- ble fly damage in horticultural systems; a certain skepticism on the part of some protagonists, primarily the farmers, already disappointed by previous proposals; a common, shared and conscious desire on the part of stakeholders in the project [76]. Seven years of findings are now available to evaluate its effectiveness, both in technical terms [72,77, 78] and economic terms [79]. Fouryears after its initiation, the profits generated exceeded the annual costs of its application. This program is currently considered in the United States as a model for success in IPM, and one of the keys to this success is due to the efficient coordination between the different protagonists in the program [80]. Furthermore, it has been subject to adaptations that have been successful in other countries, such as Japan [81] and Taiwan [82]. Other initiatives are being launched based on this model, such as on Mauritius, with the support of the International Atomic Energy Agency.

\subsection{Research actions implemented in fly bio-ecology}

Among the research actions to be developed, those relating to acquisition of knowledge of fly bio-ecology are the first to intensify. While B. cucurbitae is a fly whose biology has been well studied in the world, the same does not apply to the three other species found in Reunion (D. ciliatus, D. demmerezi and $N$. cyanescens). The aim of the studies should be to establish the main bioecological characteristics of these flies, and will cover the circadian rhythm, particularly the flies' movements between cultivated plants (Cucurbitaceae, Solanaceae) and uncultivated plants (primarily borders). Similarly, studies into the main natural enemies need to be conducted, both on predators (ants, ground beetles, rove beetles) and on parasitoids (including Psyttalia fletcheri). Tri-trophic interactions (pests, natural enemies, plants) will be a key object for study in this approach.

\subsection{Research actions into genetic structure of populations}

A work program is being initiated at the International Center for Agricultural Research for Development (CIRAD, Reunion) to analyze via micro-satellite markers the genetic 
variability of vegetable fruit fly populations, by the following parameters: host plants (wild $v s$. cultivated), altitude gradient [( 0 to 1200) $\mathrm{m}$ ] and seasonal temperatures (winter-summer). This work will enable one to specify the importance of reservoir plants and shelter plants in the reproduction of fruit flies, and gain a better knowledge of dispersal, seasonal migration and practical details of the winter season transition. The year 2008 was devoted to starting sampling on 25 sites (B. cucurbitae and D. demmerezi), tool construction ( $D$. demmerezi, $D$. ciliatus and $N$. cyanescens) and developing DNA extraction. The program will continue these preliminary activities on the four fly species concerned.

\subsection{Design of an agro-ecological management scheme for vegetable fruit flies}

Thereafter, it will be a matter of developing and evaluating a technical management package for fly populations, based on an agro-ecological approach. The design of this package is based on existing foreign experience, especially from Hawaii, while taking into account the particularities of Reunion (socio-economic characteristics of agriculture, biological characteristics of the flies present, etc.). The technical consistency of this package is an essential preliminary step. The foundation of the package is based on the following techniques: monitoring, trap plants and using new products (assisted push-pull), the Male Annihilation Technique (MAT), biological control and agro-ecological practices.

\section{Conclusions}

The control methods tested hitherto in Reunion against vegetable fruit flies have proven to be greatly insufficient in limiting damage to the crops concerned. The absence of parapheromones for all species, genuinely effective food attractants which are approved and have sufficiently longlasting action, the existence of short crop cycles repeated all year round without nohost plant zones, the ability of the flies to live for several months and move around easily, the presence of high population levels probably resulting from an imbalance, the presence of scattered plots, and the difficulty in implementing preventive measures may explain the failures observed up until now.

Fly population control should be implemented at production area level, with collective and coordinated resources, to promote a new agro-ecological balance centered on the role of functional plants, habitat management and development of natural beneficials, on a landscape scale. Other alternative methods (MAT, BAT, etc.) may be used as complements. These environmentally friendly techniques can therefore be included under Organic Agriculture and IPM approaches.

\section{Acknowledgements}

We would like to thank the Regional Council of Reunion for its assistance in enabling us to successfully conduct past and future research into vegetable fruit flies. We also express our thanks to the various collaborators in the studies, and to the project partners (FDGDON, Plant Protection Service).

\section{References}

[1] Anon., Mémento statistique agricole. La Réunion (résultats 2006), Agreste, Dir. Agric. Pêche, 2007.

[2] Ryckewaert P., Les insectes et acariens des cultures maraîchères dans les DOM-TOM : situation et perspectives, Phytoma 562 (2003) 26-31.

[3] Etienne J., Étude systématique, faunistique et écologique des Téphritides de la Réunion, École Prat. Hautes Études, Thèse, Paris, France, 1982, $100 \mathrm{p}$.

[4] Vayssières J.-F., Les relations insectes-plantes chez les Dacini (Diptera: Tephritidae) ravageurs des Cucurbitaceae à La Réunion, Cirad-Flhor, Mus. Natl. Hist. Nat., Univ. Créteil, Thesis, Paris, France, 1999, 241 p.

[5] Brévault T., Mécanismes de localisation de l'hôte chez la mouche de la tomate, 
Neoceratitis cyanescens (Bezzi) (Diptera : Tephritidae), Ensam, Thesis, Cirad-Flhor, Montpellier, France, 1999, 139 p.

[6] Vayssières J.-F., Rey J.-Y., Traoré L., Distribution and host plants of Bactrocera cucurbitae in West and Central Africa, Fruits 62 (6) (2007) 391-396.

[7] Dhillon M.K., Singh R., Naresh J.S., Sharma H.C., The melon fruit fly, Bactrocera cucurbitae: A review of its biology and management, J. Insect Sci. 5 (2005) 40.

[8] Anon., Dacus ciliatus. Distribution map, CAB-Int., U.K., 2002.

[9] Orian A.J., Moutia L.A., Fruit flies of economic importance in Mauritius, Rev. Agric. Sucr. île Maurice 39 (1960) 142-150.

[10] Lavergne R., Fleurs de Bourbon, Tome IV, Cazal (Eds), Saint Denis, La Réunion, France, $288 \mathrm{p}$.

[11] Brévault T., Datasheet on alien invasive species, Neoceratitis cyanescens Bezzi., CABI Crop Prot. Compend., U.K., 2003.

[12] Brévault T., Quilici S., Sexual attraction, male courtship and female remating in the tomato fruit fly, Neoceratitis cyanescens, J. Insect Behav. 21 (2008) 366-374.

[13] Brévault T., Quilici S., Relationships between temperature, development and survival of different life stages of the tomato fruit fly, Neoceratitis cyanescens, Entomol. Exp. Appl. 94 (2000) 25-30.

[14] Brévault T., Duyck P.-F., Quilici S., Life-history strategy of an oligophagous tephritid, Neoceratitis cyanescens, Ecol. Entomol. 33 (2008) 529-536.

[15] Brévault T., Quilici S., Factors affecting behavioural responses to visual stimuli in the tomato fruit fly, Neoceratitis cyanescens, Physiol. Entomol. 24 (1999) 333-338.

[16] Brévault T., Quilici S., Visual response of the tomato fruit fly, Neoceratitis cyanescens, to colored fruit models, Entomol. Exp. Appl. 125 (2007) 45-54.

[17] Brévault T., Quilici S., Influence of habitat pattern on visual orientation during host finding in the tomato fruit fly, Neoceratitis cyanescens, Bull. Entomol. Res. 97 (2007) 1-6.

[18] Brévault T., Quilici S., Diel patterns of reproductive activities in the tomato fruit fly, Neoceratitis cyanescens, Physiol. Entomol. 25 (3) (2000) 233-241.
[19] Ranganath H.R., Veenakumari K., Tomato (Lycopersicon esculentum Miller): A confirmed host of the melon fly Bactrocera (Zeugodacus) cucurbitae Coquillett, Insect Environ. 2 (1) (1996) 3.

[20] Fontem D.A., Gumedzoe M.Y.D., Nono W.R., Biological constraints in tomato production in the western highlands of Cameroon, Tropicultura 16 (17) (1999) 89-92.

[21] Vargas R.I., Stark J.D., Nishida T., Population dynamics, habitat preference, and seasonal distribution patterns of Oriental fruit fly and melon fly (Diptera: Tephritidae) in an agricultural area, Environ. Entomol. 19 (6) (1990) 1820-1828.

[22] Vayssières J.-F., Carel Y., Les Dacini (Diptera: Tephritidae) inféodés aux Cucurbitaceae à La Réunion : gamme de planteshôtes et stades phénologiques préférentiels des fruits au moment de la piqûre pour des espèces cultivées, Ann. Soc. Entomol. Fr. 35 (1999) 197-202.

[23] Vayssières J.-F, Carel Y., Coubès M., Duyck P.-F., Development of immature stages and comparative demography of two cucurbitattacking fruit flies in Reunion Island, Bactrocera cucurbitae and Dacus ciliatus (Diptera: Tephritidae), Environ. Entomol. 37 (2) (2008) 307-314.

[24] Vargas R.I., Walsh W.A., Kanehisha D., Stark J.D., Nishida T. , Comparative demography of three Hawaiian fruit fly (Diptera: Tephritidae) at alternating temperatures, Ann. Entomol. Soc. Am. 93 (1) (2000) 75-81.

[25] Vayssières J.-F., Dal F., Responses of the Ethiopian fruit fly, Dacus ciliatus Loew (Diptera: Tephritidae), to coloured rectangles, spheres and ovoids, Proc. 6th Int. Fruit Fly Symp., 6-10 May 2002, Stellenbosch, S. Afr., pp. 111-116.

[26] Dong Y.J., Cheng L.L., Chen C.C., Laboratory bioassay of 10 insecticides against the melon fly (Bactrocera cucurbitae), J. Agric. Res. Chin. 51 (4) (2002) 66-72.

[27] Hsu J.C., Feng H.T., Susceptibility of melon fly (Bactrocera cucurbitae) and oriental fruit fly (B. dorsalis) to insecticides in Taiwan, Plant Prot. Bull. (Taichung) 44 (4) (2002) 303315.

[28] Liquido N.J., Fruit on the ground as a reservoir of resident melon fly (Diptera: Tephritidae) populations in papaya orchards, Environ. Entomol. 20 (2) (1991) 620-625. 
[29] Martin T., Assogba-Komlan F., Houndete T., Hougard J.M., Chandre F., Efficacy of mosquito netting for sustainable small holders' cabbage production in Africa, J. Econ. Entomol. 99 (2006) 450-454.

[30] Froissart R., Gerard M., Vaissiere B.E., Integrated production of out of season cantaloupes in West Africa, Fruits 50 (5) (1995) 359-374.

[31] Vaissière B.E., Froissart R., Pest management and pollination of cantaloupes grown under spunbonded row covers in West Africa, J. Hortic. Sci. 71 (5) (1996) 755-766.

[32] Truong H.X., Rapusas H.R., Valdez E.M., Marquez L.V., Casimero M.C., Communitybased IPM [Integrated Pest Management] in rice-bitter gourd cropping system., Philipp. Entomol. 17 (2) (2003) 183.

[33] Langlais C., Ryckewaert P., Guide to sheltered vegetable cultivation in the humid tropics, Cirad-Flhor, Montpellier, France, 2001, $92 \mathrm{p}$.

[34] Cheng C.H., Ho S.C., Evaluation of the effects of ultraviolet-absorbing film on the population of insect pests and yield of muskmelon, Plant Prot. Bull. (Taipei) 39 (4) (1997) 289-304.

[35] Boller E.F., Biotechnical methods for the management of fruit fly populations, in: Cavalloro R. (Ed.), Fruit flies of economic importance 82, Proc. CEC/IOBC Int. Symp., Athens, Greece, 1983, pp. 342-351.

[36] Vargas R.I., Miller N.W., Stark J.D., Field trials of spinosad as a replacement for naled, DDVP, and malathion in methyl eugenol and cue-lure bucket traps to attract and kill male oriental fruit flies and melon flies (Diptera: Tephritidae) in Hawaii, J. Econ. Entomol. 96 (6) (2003) 1780-1785.

[37] Matsui M., Nakamori H., Kohama T., Nagamine Y., The effect of male annihilation on a population of wild melon flies, Dacus cucurbitae Coquillett (Diptera: Tephritidae) in Northern Okinawa, Jpn. J. Appl. Entomol. Zool. 34 (4) (1990) 315-317.

[38] Royer L., Delisle J., Utilisation des pièges à phéromone sexuelle dans la gestion des ravageurs, in: Regnault-Roger C. (Ed.), Enjeux phytosanitaires pour l'agriculture et I'environnement, Lavoisier, Paris, France, 2005.

[39] Leonhardt B.A., Mastro V.C., Leonard D.S., McLane W., Reardon R.C., Thorpe K.W.
Control of low-density gypsy moth (Leidoptera: Lymantriidae) populations by mating disruption with pheromone, J. Chem. Ecol. 22 (1996) 1255-1272.

[40] Qureshi Z.A., Hussain T., Efficacy of Nu-lure and protein hydrolysate baits in controlling Ethiopian melon fly Dacus ciliatus, Pak. J. Agric. Res. 13 (2) (1992) 150-154.

[41] Akhtaruzzaman M., Zinnatul A., Ali S.M.M., Efficacy of different bait sprays for suppressing fruit fly on cucumber, Bull. Inst. Trop. Agric. (Kyushu Univ.) 23 (2000) 15-26.

[42] Satpathy S., Rai S., Luring ability of indigenous food baits for fruit fly, Bactrocera cucurbitae (Coq.), J. Entomol. Res. 26 (3) (2002) 249-252.

[43] Jiji T., Napolean A., Stonehouse J., Verghese A., Efficient food baits for trapping fruit flies, Insect Environ. 9 (3) (2003) 143-144.

[44] Barry J.D., Miller N.W., Pinero J.C., Tuttle A., Mau R. F.L., Vargas R.I., Effectiveness of protein baits on melon fly and oriental fruit fly (Diptera: Tephritidae): attraction and feeding, J. Econ. Entomol. 4 (2006) 1161-1167.

[45] Robinson A.S., Hooper G., Fruit flies, their biology, natural enemies and control, Elsevier, Amst., Neth., 1989.

[46] Fabre F., Ryckewaert P., Duyck P.F., Chiroleu F., Quilici, S., Comparison of the efficacy of different food attractants and their concentration for melon fly (Diptera: Tephritidae), J. Econ. Entomol. 96 (1) (2003) 231-238.

[47] Duyck P.F., Quilici S., Fabre F., Ryckewaert P., Comparison and optimization of the efficacy of different food attractants for both sexes of the melon fly, Bactrocera cucurbitae (Coquillett) (Diptera:Tephritidae), Proc. 6th Int. Symp. Fruit flies of economic importance, Stellenbosch, S. Afr., 2002 May 6-10, 2004, pp. 351-354.

[48] Duyck P.F., Rousse P., Ryckewaert P., Fabre F., Quilici S., Influence of adding borax and modifying $\mathrm{pH}$ on effectiveness of food attractants for melon fly (Diptera: Tephritidae), J. Econ. Entomol. 97 (3) (2004) 11371141.

[49] Rousse P., Duyck P.F., Quilici S., Ryckewaert P., Development and optimization of food attractants for the melon fly Bactrocera cucurbitae (Coquillet) (Diptera: Tephritidae), Rev. Agric. Sucr. île Maurice 83 (2/3) (2004) 43-49. 


\section{P. Ryckewaert et al.}

[50] Rousse P., Duyck P.F., Quilici S., Ryckewaert P., Adjustment of field cage methodology for testing food attractants for fruit flies (Diptera: Tephritidae), Ann. Entomol. Soc. Am. 98 (3) (2005) 402-408.

[51] Prokopy R.J., Miller N.W., Pinero J.C., Barry J.D., Tran L.C., Oride L., Vargas R., Effectiveness of GF-120 fruit fly bait spray applied to border area plants for control of melon flies (Diptera: Tephritidae), J. Econ. Entomol. 96 (5) (2003) 1485-1493.

[52] Stark J., Vargas R., Miller N., Toxicity of spinosad in protein bait to three economically important tephritid fruit fly species (Diptera: Tephritidae) and their parasitoids (Hymenoptera: Braconidae), J. Econ. Entomol. 97 (3) (2004) 911-915.

[53] Sookar P., Seewooruthun S.I., Khayratee F., Assessment of protein baits for the monitoring and control of fruit flies (Diptera: Tephritidae), Rev. Agric. Sucr. Île Maurice 80 (2001) 287-294.

[54] Revis H.C., Miller N.W., Vargas R., Effects of aging and dilution on attraction and toxicity of GF-120 fruit fly bait spray for melon fly control in Hawaii, J. Econ. Entomol. 97 (5) (2004) 1659-1665.

[55] Miller N., Vargas R., Prokopy R., Mackey B., State-dependent attractiveness of protein bait and host fruit odor to Bactrocera cucurbitae (Diptera: Tephritidae) females, Ann. Entomol. Soc. Am. 97 (5) (2004) 1063-1068.

[56] Hurtrel B., Biologie du développement et écologie comportementale de deux parasitoïdes de mouches des fruits à la Réunion, Univ. Rennes, Thesis, Rennes, France, 2000, $157 \mathrm{p}$.

[57] Bautista R.C., Harris E.J., Vargas R.I., Jang E.B., Parasitization of melon fly (Diptera: Tephritidae) by Fopius arisanus and Psyttalia fletcheri (Hymenoptera: Braconidae) and the effect of fruit substrates on host preference by parasitoids, Biol. Control 30 (2) (2004) 156-164.

[58] Quilici S., Hurtrel B., Messing R.H., Montagneux B., Barbet A., Gourdon F., Malvolti A., Simon A., Successful acclimatization of Psyttalia fletcheri (Braconidae: Opiinae) for biological control of the melon fly, Bactrocera cucurbitae (Diptera: Tephritidae), on Reunion Island, Proc. 6th Int. Symp. Fruit flies of economic importance, Stellenbosch, S. Afr., 6-10 May 2002, pp. 457-459.
[59] Vargas R.I., Long J., Miller N.W., Delate K., Jackson C.G., Uchida G.K., Bautista R.C., Harris E.J., Releases of Psyttalia fletcheri (Hymenoptera: Braconidae) and sterile flies to suppress melon fly (Diptera: Tephritidae) in Hawaii, J. Econ. Entomol. 97 (5) (2004) 1531-1539.

[60] Rousse P., Gourdon F., Quilici S., Host specificity of the egg pupal parasitoid Fopius arisanus (Hymenoptera: Braconidae) in La Reunion, Biol. Control 37 (3) (2006) 284-290.

[61] Fetoh B.E.A., Recent record of parasitoid species of cucurbit fruit fly, Dacus ciliatus (Loew) (Diptera: Tephritidae) in Egypt, Egypt, J. Biol. Pest Control 13 (1/2) (2003) 127.

[62] Ehler L.E., Integrated Pest Management (IPM): definition, historical development and implementation, and the other IPM, Pest Manag. Sci. 62 (2006) 787-789.

[63] Sekiguchi Y., Eradication of the melon fly (Dacus cucurbitae) from Amani Islands of Japan, Q. Newsl. Asia Pac. Plant Prot. Comm. 33 (2) (1990) 19-20.

[64] Ito Y., Kakinohana H., Yamagishi M., Kohama T., Eradication of the melon fly, Bactrocera cucurbitae, from Okinawa, Japan, by means of the sterile insect technique, with special emphasis on the role of basic studies, J. Asia Pac. Entomol. 6 (2) (2003) 119129.

[65] Ito Y., Effect of eradication of the Oriental fruit fly, Bactrocera dorsalis, on the population density of the melon fly, Bactrocera cucurbitae, in the Ryukyu Archipelago, estimated from the number of male flies captured by attractant traps, Appl. Entomol. Zool. 40 (4) (2005) 625-630.

[66] Nicholls C.I., Altieri M.A., Agroecological bases of ecological engineering for pest management, in: Gurr G.M., Wratten S.D., Altieri M.A. (Eds.), Ecological engineering for pest management. Advances in habitat manipulation for arthropods, CSIRO, Collingwood, Aust., CABI, Wallingford, U.K., 2004, pp. 33-54.

[67] Ferron P., Deguine J.-P., Crop protection, biological control, habitat management and integrated farming, Agron. Sustain. Dev. 25 (2005) 1-8.

[68] Altieri M.A., The ecological role of biodiversity in agroecosystems, Agric. Ecosyst. Environ. 74 (1999) 19-31. 
[69] Nishida T., Bess H.A., Studies on the ecology and control of the melon fly Dacus (Strumeta) cucurbitae Coquillett (Diptera: Tephritidae), Hawaii Agric. Exp. Stn. Tech. Bull. 84 (1957) 1-44.

[70] McQuate G.T., Assessment of corn pollen as a food source for two tephritid fruit fly species, Environ. Entomol. 32 (1) (2003) 141150.

[71] Prokopy R.J., Miller N.W., Pinero J.C., Oride L., Chaney N., Revis H., Vargas R., How effective is GF-120 fruit fly bait spray applied to border area sorghum plants for control of melon flies (Diptera: Tephritidae), Fla. Entomol. 87 (3) (2004) 354-360.

[72] McQuate G., Vargas R., Assessment of attractiveness of plants as roosting sites for the melon fly, Bactrocera cucurbitae, and oriental fruit fly, Bactrocera dorsalis, J. Insect Sci. 7 (2007) 57.

[73] Deguine J.-P., Ferron P., Russell D., Crop protection: from agrochemistry to agroecology, Sci. Publ., Enfield, NH, U.S.A., 2009.

[74] Tan K.H., Area-wide control of fruit flies and other insect pests, CABI, Wallingford, U. K., 2000.

[75] Vargas R.I., Area-wide pest management for exotic fruit flies in Hawaii, in: FLC awards program, FLC-TPWG Natl. Meet., May 2004, San Diego, Calif., U. S. A., pp. 15-16.

[76] Vargas R.I., Highlights and milestones of the Hawaii area-wide fruit fly pest management program, in: Proc. 6th Ann. Meet. Rev. Hawaii fruit fly area-wide management programme, April 16-19, 2007, Waikoloa, Hawaii, U. S. A.
[77] Jang E.B., Klungness L.M., McQuate G.T., Extension of the use of augmentoria for sanitation in a cropping system susceptible to the alien tephritid fruit flies (Diptera: Tephritidae) in Hawaii, J. Appl. Sci. Environ. Manag. 11 (2007) 239-248.

[78] McQuate G., Assessment of border bait sprays and male annihilation for Bactrocera spp. suppression in papaya orchards, In: Proc. 6th Ann. Meet. Rev. Hawaii fruit fly area-wide management programme, April 16-19, 2007, Waikoloa, Hawaii, U. S. A.

[79] McGregor A.M., An economic evaluation of the Hawaii fruit fly area-wide pest management program, Trade Dev. Off., U.S.A., 2007, $81 \mathrm{p}$.

[80] Mau R.F.L., Jang E.B., Vargas R.I., The Hawaii area-wide fruit fly pest management programme: Influence of partnerships and a good education programme, in: Vreysen M.J.B., Robinson A.S., Hendrichs J. (Eds.), Area-wide control of insect pests. From research to field implementation, Springer, 2007.

[81] Koyama J., Kahinohana H., Miyatake T., Eradication of the melon fly, Bactrocera cucurbitae, in Japan: Importance of behavior, ecology, genetics, and evolution, Ann. Rev. Entomol. 49 (2004) 331-349.

[82] Huang T.C., Expansion of the area wide fruit fly management program in Taiwan. Some contributions from Hawaii, in: Proc. 6th Ann. Meet. Rev. Hawaii fruit fly area-wide management programme, April 16-19, 2007, Waikoloa, Hawaii, U. S. A. 
Las moscas de las frutas (Diptera: Tephritidae) en verduras en la Reunión (océano Índico): estado de los conocimientos, métodos de control y perspectivas de gestión.

Resumen -- Importancia de las moscas de las frutas en cultivos de hortalizas. Los cultivos de hortalizas ocupan una posición determinante en la producción agrícola en la Reunión (océano Índico). No obstante, existen numerosas plagas así como enfermedades, que suponen una amenaza para la rentabilidad de este sector agrícola. Las moscas de las frutas (Diptera: Tephritidae) se clasifican entre las plagas principales de las solanáceas y de las cucurbitáceas (pepino, calabacín, melón, etc.). Se observaron frecuentemente pérdidas de cerca del $80 \%$ de las cosechas de tomate y del $100 \%$ de cucurbitáceas. Inventario y distribución. Cuatro especies de moscas de las frutas pertenecientes a la familia de los Tephritidae provocan importantes daños en los cultivos de verduras en la Reunión: Bactrocera cucurbitae (Coquillet), Dacus ciliatus Loew y D. demmerezi (Bezzi) en los cucurbitáceos, y Neoceratitis cyanescens (Bezzi) en las solanáceas (principalmente los tomates). La distribución de cada uno de ellos está presentada. Biología y comportamiento. En la Reunión en los años 1990 se realizaron ciertos estudios sobre la biología así como sobre el comportamiento de las cuatro moscas de las frutas. Se resumieron sus principales características biológicas. Métodos de control de las poblaciones empleadas en la Reunión. Se exponen diversos métodos empleados actualmente en la Reunión contra estas moscas de las frutas: lucha química, medidas preventivas (saneamiento), control físico, control biotécnico [color de las trampas, técnica de anihilación del macho (MAT), así como técnica de empleo de cebos (BAT)], y lucha biológica. En la Reunión no se emplean otros métodos de lucha como la lucha antiparasitaria integrada o la técnica del insecto estéril. Perspectivas de puesta en marcha de la gestión agro-ecológica de las moscas de las frutas en cultivo de hortaliza en la Reunión. Esta parte presenta tanto las acciones de investigación puestas en marcha en bio-ecología de la mosca, como las acciones de investigación en la estructura genética de las poblaciones, o incluso la concepción de un sistema de gestión agro-ecológico para las moscas de las frutas de las verduras. Conclusiones. Los métodos empleados independientemente unos de otros no demostraron su eficacia para el control de las poblaciones de las Tephritidae. Se necesita un acercamiento más íntegro, que tome en cuenta la escala del paisaje y de su mosaico de hábitats, en concreto las plantas espontáneas, cuyo papel debe considerarse en el marco de una gestión agro-ecológica de las poblaciones de estas plagas.

Reunión / hortalizas (plantas) / Tephritidae / Bactrocera cucurbitae / Dacus ciliatus / Dacus demmerezi / Neoceratitis cyanescens / control de plagas / métodos de control 